\title{
The Impact of Suckling and Post-weaning Period on Blood Chemistry of Piglets
}

\author{
Vladimír Petrovič ${ }^{1}$, Jaroslav Novotný², Vladimír Hisira ${ }^{1}$, Róbert Link ${ }^{2}$, L’ubomír Leng ${ }^{3}$, \\ Gabriel Kováč ${ }^{1}$ \\ ${ }^{1}$ University of Veterinary Medicine, Clinic of Ruminants, Košice, Slovakia \\ ${ }^{2}$ University of Veterinary Medicine, Clinic of Swine, Košice, Slovakia \\ ${ }^{3}$ Institute of Animal Physiology, Slovak Academy of Sciences, Košice, Slovakia
}

Received July 17, 2008

Accepted November 12, 2008

\begin{abstract}
The aim of this study was to determine the impact of dietary changes during the suckling and post-weaning period on selected haematological, immunological and metabolic indices as well as the macro- and micro-mineral and antioxidant status of piglets. Twelve Large White piglets were kept according to the standards of pig rearing used in Slovakia until the end of the post-weaning period. Blood samples were taken from the piglets at the age of 30 days (the end of the suckling period) and 2 months (the end of the post-weaning period). At the end of the post-weaning period higher indices were found for RBC $(P<0.01)$, Hb $(P<0.01)$, WBC $(P<0.05)$, total Ig $(P<0.05)$, AST $(P<0.01)$, urea $(P<0.01)$, Se $(P<0.05)$, GSH-Px $(P<0.001)$, -SH groups $(P<0.01)$ and lower indices of albumin $(P<0.05)$, ALP $(P<0.001)$, LDH $(P<0.01)$, pancreatic amylase $(P<0.01)$, total lipids $(P<0.01)$, glucose $(P<0.01)$, total cholesterol $(P<0.01)$, bilirubin $(P<0.001)$, Ca $(P<0.01)$, SOD $(P<0.01)$, MDA $(P<0.01)$, vitamin A $(P<0.05)$, and vitamin $\mathrm{E}(P<0.05)$ as compared to the end of suckling period. These results indicate that the dietary changes during suckling and post-weaning periods affected the majority of observed blood indices in piglets.
\end{abstract}

Nutrition, diets, immunoglobulins, haematology, blood indices

The characteristic features of the suckling period of piglets are an extremely high growth rate and rapid development of the organism (especially bones and parenchymatous organs) enabled by unique milk nutrition with a high fat content (Trávníček 1960) provided by the dam. Thus not only rapid growth but also deposition of fat in tissues of the body of piglets is possible. During the suckling period, piglets are routinely supplemented with concentrated creep feed (pre-starter) offered to them ad libitum from day 7 after birth. The piglets receive this diet until they reach the weaning age. Usually, a three-day weaning period is a transition phase from the milk nutrition to starter diets. During the post-weaning period, another complete feed for weaned piglets is fed. Gu and Li (2003) and $\mathrm{Wu}$ et al. (2007) reviewed the important role of fat and amino acids in swine nutrition and production, respectively. The feeding of complete diet for weaned piglets rich in nitrogen compounds and a balanced composition of essential nutrients enhances a remarkable increase of body mass via incorporation of amino acids mainly into the skeletal muscles. Therefore, the level of piglet nutrition plays an important role in their healthy growth and development that is very intensive during the first 2 months of their postnatal life.

The influence of nutrition during the suckling, weaning and post-weaning period of piglets on their immunocompetence (Klobasa et al. 1987; Salmon 1999), metabolism (Holub et al. 1978ab; Holub 1982; 1990; 1994), morphology of the gastro-intestinal tract (Van Beers-Schreurs 1996; Gu et al. 2002) and the activities of digestive enzymes in duodenum and jejunum (Makkink et al. 1994; Wattanakul et al. 2007) are well described. However, a complex knowledge of the concentrations of antioxidants and minerals as well as the activities of enzymes in the blood of piglets in these phases is limited.

Therefore, the aim of our study was to determine the effect of dietary changes during Address for correspondence:

MVDr. Vladimír Petrovič, PhD.

University of Veterinary Medicine

Clinic of Ruminants

Komenského 73, 04181 Košice

Slovakia

E-mail: vpetrovic@centrum.sk

http://www.vfu.cz/acta-vet/actavet.htm 
the suckling and post-weaning period on selected haematological, immunological, and metabolic indices as well as the macro- and micro-mineral and antioxidant status in piglets.

\section{Materials and Methods}

One litter of Large White piglets $(\mathrm{n}=12)$, of average body mass $(\mathrm{BM})$ of $1.6 \mathrm{~kg}$, were treated with Ferridextran inj. (Spofa, CZ) and Selevit inj. (Biotika, SR) at the doses of 1.0 and $1.0 \mathrm{ml} \cdot \mathrm{kg}^{-1}$ of BM on the day of birth, respectively. The piglets were nursed by their dam for 32 days. The milk of Large White sows contains per $100 \mathrm{~g}$ : total lipids $9.31 \mathrm{~g}$; total cholesterol, $0.91 \mathrm{~g}$; total proteins, $4.69 \mathrm{~g}$; total solid, $5.77 \mathrm{~g}$ (Link et al. 2007), and per liter: Ca, 1.93 g; P, 1.15 g; Mg, 0.11 g; Na, 0.38 g; K, 0.72 g; Cu, 0.95 mg; Fe, 0.4 mg; Zn; 7.46 mg; Se, 0.016 mg. Csapo et al. (1995) obtained similar concentrations of macro- and micro-elements and found the following amounts of vitamin A and $E$ in the sow milk: $0.92 \pm 0.14$ and $2.53 \pm 0.23 \mathrm{mg} \cdot \mathrm{kg}^{-1}$, respectively.

At the age of 7 days, the nutrition was enriched with concentrated diet (OŠ-1) for sucking piglets (Tajba, SR) (Table 1).

Table 1. Composition of concentrated diet (OŠ-1) for sucking piglets fed from $7^{\text {th }}$ day up to the age of 30 days

\begin{tabular}{|l|c|l|c|}
\hline Component & $\%$ & Component & $\%$ \\
\hline Corn & 37 & Methionine & 0.1 \\
\hline Soybean extracted ground meal & 24 & Threonine & 0.2 \\
\hline Barley & 10 & $\mathrm{Ca}\left(\mathrm{H}_{2} \mathrm{PO}_{4}\right)_{2} \cdot \mathrm{H}_{2} \mathrm{O}$ & 0.7 \\
\hline Wheat & 5 & $\mathrm{CaCO}$ & 1.8 \\
\hline Wheat bran & 7 & $\mathrm{NaCl}$ & 0.45 \\
\hline Wheat ground & 6 & Vitamin-mineral premix & 0.03 \\
\hline Whey powder & 10 & Kenzyme WP Dry New & 0.05 \\
\hline Lysine & 0.4 & & \\
\hline
\end{tabular}

OŠ-1 contained per $1 \mathrm{~kg}$ of DM: vitamin A, $8000 \mathrm{U}$; vitamin D, $1000 \mathrm{U}$; NC, $180 \mathrm{~g}$; DF, 30-40 g; lysine, $11.5 \mathrm{~g}$; treonine, $5.5 \mathrm{~g}$; methionine and cysteine, $6.3 \mathrm{~g}$; Ca, $8.0 \mathrm{~g}$; P, $6.7 \mathrm{~g}$; Na, $2.0 \mathrm{~g}$; vitamin E, $20 \mathrm{mg}$; vitamin $\mathrm{B}_{2}, 3 \mathrm{mg}$; choline, $600 \mathrm{mg}$; Fe, $125 \mathrm{mg}$; Zn, $100 \mathrm{mg}$; Cu, $10 \mathrm{mg}$; Se, $0.1 \mathrm{mg}$; vitamin $\mathrm{B}_{12}, 20 \mu \mathrm{g}$

a-supplied per kg of diet: $\alpha$ amylase, $200 \mathrm{U}$; endo-1,3,(4)- $\beta$ glucanase, $1175^{12} \mathrm{U}$; endo-1,4- $\beta$ glucanase, $2000 \mathrm{U}$; endo-1,4- $\beta$ xylanase, $1000 \mathrm{U}$; bacilolisine, $225 \mathrm{U}$; 6-fytase, 499.5 FYT

The weaning of piglets was performed between days 30 and 32 after birth by reducing the sucking from 3-times to 2-times to once a day, respectively. During these three days the dietary supplement contained both OŠ- 1 and OŠ-2 diets for weaned pigs (Tajba, SR), mixed at a ratio $2: 1,1: 1$ and finally $1: 2$, respectively.

During the post-weaning period (i.e. from day 32 until the age of 2 months), the piglets were fed the diet OŠ-2 (Table 2).

Table 2. Composition of concentrated feed (OŠ-2) for weaned piglets fed from $32^{\text {nd }}$ day up to the age of 2 months before blood sampling

\begin{tabular}{|l|r|l|l|}
\hline Component & $\%$ & Component & $\%$ \\
\hline Corn & 42.6 & Lysine & 0.2 \\
\hline Soybean extracted ground meal & 23.7 & Threonine & 0.1 \\
\hline Barley & 10 & $\mathrm{Ca}\left(\mathrm{H}_{2} \mathrm{PO}_{4}\right)_{2} \cdot \mathrm{H}_{2} \mathrm{O}$ & 0.7 \\
\hline Wheat & 5 & $\mathrm{CaCO}_{3}$ & 2.0 \\
\hline Wheat bran & 5 & $\mathrm{NaCl}$ & 0.3 \\
\hline Wheat ground & 5 & Vitamin-mineral premix & 0.03 \\
\hline Whey powder & 5 & Kenzyme WP Dry New & 0.1 \\
\hline
\end{tabular}

OŠ-2 contained per $1 \mathrm{~kg}$ of DM: vitamin A, $8000 \mathrm{U}$; vitamin $\mathrm{D}_{3}, 1000 \mathrm{U}$; lysine, $11.5 \mathrm{~g}$; treonine, $7.5 \mathrm{~g}$; methionine and cysteine, $6.3 \mathrm{~g}$; Ca, $7.0 \mathrm{~g}$; P, $5.8 \mathrm{~g}$; Na, $1.5 \mathrm{~g}$; vitamin E, $20 \mathrm{mg}$; vitamin B2, $3 \mathrm{mg}$; choline, $600 \mathrm{mg}$; Fe, 125 $\mathrm{mg}$; Zn, $100 \mathrm{mg}$; Cu, $10 \mathrm{mg}$; Se, $0.1 \mathrm{mg}$; vitamin B12, $20 \mu \mathrm{g}$

a-supplied per kg of diet: $\alpha$ amylase, $200 \mathrm{U}$; endo-1,3,(4)- $\beta$ glucanase, $1175 \mathrm{U}$; endo-1,4- $\beta$ glucanase, $2000 \mathrm{U}$; endo-1,4- $\beta$ xylanase, $1000 \mathrm{U}$; bacilolisine, $225 \mathrm{U}$; 6-fytase, 499.5 FYT

The piglets were placed in a large pen with a fibre-board, and had free access to the pen with their dam only during the suckling period. All piglets had free access to water and creep feed. The room temperature of $24{ }^{\circ} \mathrm{C}$ 
was kept during the whole experiment but the pen with piglets was heated with a lamp at the temperature of $32{ }^{\circ} \mathrm{C}$ until weaning.

At the age of 30 days, the piglets were weighed (average BM of $8.2 \mathrm{~kg}$ ) and blood was collected from sinus ophtalmicus (Kováč et al. 1990) into heparinized tubes and centrifuged for blood plasma at $1180 \mathrm{~g}$ for $15 \mathrm{~min}$ and allowed to clot to obtain blood serum. The samples of blood, plasma and serum were immediately frozen and stored at $-24^{\circ} \mathrm{C}$. The same procedure was performed at the age of 60 days (at the end of the post-weaning period) when the average body mass was $15.9 \mathrm{~kg}$ per animal.

The standard kits from Randox, UK were used to determine the activities of AST, ALT, ATP, $\gamma$ GT, LDH, pancreatic amylase in serum and concentration of glucose in blood as well as measurement of total proteins, albumin, creatine, urea, total cholesterol, total lipids, bilirubin in serum and phosphorus in milk and serum by spectrometer Alizé (Lisabio, Fr.). The concentrations of $\mathrm{Na}, \mathrm{K}, \mathrm{Ca}, \mathrm{Mg}, \mathrm{Cu}, \mathrm{Fe}$ and $\mathrm{Zn}$ in milk, concentrated feed and serum were analysed by flame AAS method (AAnalyst 100, Perkin-Elmer). The concentration of selenium in milk, concentrated feed and blood was measured using the fluorimetric method of Rodriguez et al. (1994). The indices of blood picture were assessed by the animal blood counter (ABC VET 16p, Trigon s.r.o.) and total immunoglobulins in serum by Spekol 211 (Carl-Zeiss Jena). Activity of blood glutathione peroxidase (GSHPx, EC 1.11.1.9) was determined using the Ransel kit (Randox, UK). Concentration of malondialdehyde in plasma was measured with the modified fluorimetric method according to Jo and Ahn (1998). Superoxide dismutase (SOD, EC 1.15.1.1) activity (Arthur and Boyne 1985) in erythrocytes was analyzed using kits from Randox, UK. Ellman's method (1958) was used to determine the concentration of sulphhydryl groups in plasma. The concentrations of vitamin A and E were assessed using HPLC technique according to Tučková and Kaštel' (1999).

The experiment was carried out in accordance with established standards for animal care and use. The protocol was approved by local Ethics Committee.

Statistical analysis of all results was done using paired Student's $t$-test.

\section{Results and Discussion}

At the time of weaning, the immune system of piglets is not fully mature (Hampl et al. 1980; Trebichavský et al. 1988; Kovář et al. 2002; Brown et al. 2006) and the immunity is still developing by contact of immune cells with viruses and bacteria naturally present in the environment. The indices of white blood cells (WBC), total immunoglobulins and albumin revealed significant differences in young pigs of two months of age (the end of the post-weaning period) compared to one-month-old piglets (the end of the suckling period). The WBC count showed an increasing tendency during the first two months of

Table 3. Haematological and immunological indices of piglets

\begin{tabular}{|l|c|c|}
\hline Indices & $\begin{array}{c}\text { End of suckling period } \\
\text { (day } 30 \text { after birth) }\end{array}$ & $\begin{array}{c}\text { End of post-weaning period } \\
\text { (day } 60 \text { after birth) }\end{array}$ \\
\hline $\mathrm{RBC}\left(\mathrm{T} \cdot \mathrm{l}^{-1}\right)$ & $6.188 \pm 0.407$ & $7.14 \pm 0.282^{* *}$ \\
\hline $\mathrm{Hb}\left(\mathrm{g} \cdot \mathrm{l}^{-1}\right)$ & $99.4 \pm 11.4$ & $119.6 \pm 14.08^{* *}$ \\
\hline $\mathrm{MCV}\left(\mathrm{f} \cdot \mathrm{l}^{-1}\right)$ & $50.8 \pm 5.514$ & $53.14 \pm 1.676$ \\
\hline $\mathrm{MCH}\left(\mathrm{f} \cdot \mathrm{mol}^{-1}\right)$ & $16.12 \pm 1.847$ & $16.73 \pm 0.472$ \\
\hline $\mathrm{MCHC}\left(\mathrm{mmol} \cdot \cdot^{-1}\right)$ & $31.72 \pm 0.691$ & $31.51 \pm 0.302$ \\
\hline $\mathrm{Tc}\left(\mathrm{G} \cdot \mathrm{l}^{-1}\right)$ & $710.6 \pm 186$ & $701.0 \pm 104.9$ \\
\hline $\mathrm{WBC}\left(\mathrm{G} \cdot \mathrm{l}^{-1}\right)$ & $14.84 \pm 3.555$ & $17.47 \pm 2.692^{*}$ \\
\hline Albumin $\left(\mathrm{g} \cdot \mathrm{l}^{-1}\right)$ & $39.29 \pm 3.428$ & $36.17 \pm 1.545^{*}$ \\
\hline Total $\mathrm{Ig}(\mathrm{U} \mathrm{ZST})$ & $24.57 \pm 2.487$ & $27.66 \pm 2.821^{*}$ \\
\hline
\end{tabular}

Results are presented as mean $\pm \mathrm{SD}, \mathrm{n}=12 ; * P<0.05 ; * * P<0.01$ Symbols: red blood cell (RBC); haemoglobin (Hb); mean corpuscular volume $(\mathrm{MCV})$ and mean corpuscular haemoglobin $(\mathrm{MCH})$ values; mean corpuscular haemoglobin concentration (MCHC); thrombocytes (Tc); white blood cell (WBC); total immunoglobulins (Total Ig), units of zinc-sulphate test (U ZST)

The activities of alkaline phosphatase (ALP), lactate dehydrogenase (LDH) and pancreatic amylase in serum reflect the growth of bones, production of energy and metabolism of postnatal life (Table 3 ), similar to findings of Zelníčková et al. (2006). Similarly, the erythrocyte numbers and haemoglobin content age of animals (Table 3). Our explanation of these changes is based on the fact that in the early postnatal ontogeny the extremely rapid development of organs is responsible for the formation and maturation of RBC. Moreover, the life span of erythrocytes is above 120 days. Egeli et al. (1998) found the physiological $\mathrm{Hb}$ amount to be up to $80 \mathrm{~g} \cdot \mathrm{l}^{-1}$; this indicates that the piglets in our experiment did not suffer from anaemia. differed depending on the 
Table 4. Activities of aspartate amino transferase (AST), alanine amino transferase (ALT), alkaline phosphatase (ALP), gamma glutamyl transferase $(\gamma \mathrm{GT})$, lactate dehydrogenase $(\mathrm{LDH})$ and pancreatic amylase $\left(\mu \mathrm{kat} \cdot \mathrm{l}^{-1}\right)$ in blood serum of piglets

\begin{tabular}{|l|c|c|}
\hline Indices & $\begin{array}{c}\text { End of suckling period } \\
\text { (day 30 after birth) }\end{array}$ & $\begin{array}{c}\text { End of post-weaning period } \\
\text { (day 60 after birth) }\end{array}$ \\
\hline AST & $0.414 \pm 0.069$ & $0.590 \pm 0.101^{* *}$ \\
\hline ALT & $0.669 \pm 0.204$ & $0.834 \pm 0.148$ \\
\hline ALP & $17.78 \pm 3.241$ & $5.416 \pm 1.166^{* * *}$ \\
\hline$\gamma$ GT & $0.488 \pm 0.266$ & $0.34 \pm 0.069$ \\
\hline LDH & $24.83 \pm 2.32$ & $18.4 \pm 2.964^{* *}$ \\
\hline Pancreatic amylase & $44.48 \pm 6.93$ & $37.51 \pm 5.73^{* *}$ \\
\hline
\end{tabular}

Results are presented as mean $\pm \mathrm{SD}, \mathrm{n}=12$; ** $P<0.01$; *** $P<0.001$ carbohydrates, respectively. All these processes are extremely efficient during the suckling period. The significantly higher activities of ALP and pancreatic amylase in the serum of piglets at the end of the suckling period versus the end of the post-weaning period (Table 4), corroborate this phenomenon. On the other hand, the activity of aspartate amino transferase was found to be significantly lower in serum of pigs at the end of the suckling period. Tang et al. (1999) found a reduction of the specific ALP activities in duodenum and jejunum during the weaning of pigs.

The milk of sows contains high amounts of fat and carbohydrates (Trávníček 1960) that surpass those of the complete feed rich in nitrogen compounds and given during the post-weaning period. Total lipids, glucose, total cholesterol, bilirubin and urea are primarily affected by the nutritional value of the feed (Lauridsen and Jensen 2007; Trujillo-Coutino et al. 2007). Significant differences found in these indices in our experimental piglets confirm this view (Table 5). Although there were age-dependent changes in the concentrations of the individual amino acids in the blood of piglets observed (Baranyiová et al. 1990), our results did not reveal a significant difference in the amount of total proteins.

During the whole suckling period, the sow's milk was the main source of nutrition for piglets, but the concentrated feed for sucking piglets was readily eaten and its consumption increased. The concentration of macroand micro-elements in the blood serum depends on the nutritional composition of diet, age and physiological state of the animal. The concentrations of $\mathrm{Na}, \mathrm{K}, \mathrm{Mg}, \mathrm{Fe}, \mathrm{Zn}, \mathrm{Cu}$ in the serum were similar, whereas the concentration of calcium in the serum and selenium in the blood reflected the disproportion between their amount in the feed given to piglets during both periods as well as their physiological requirements 
for healthy growth (Table 6). Similarly, Egeli et al. (1998) found the concentration of minerals in the blood of piglets unaffected by their age.

Especially micro-elements are considered as antioxidant nutrients, $\mathrm{Fe}$ as a part of catalase, $\mathrm{Cu}$ and $\mathrm{Zn}$ as a part of superoxide dismutase (SOD) and $\mathrm{Se}$ as a part of glutathione peroxidase (GSH-Px) and all play interdependent roles in the antioxidant protection. The concentration of Se in the diets fed during the suckling period (milk; $0.016 \mathrm{mg} \cdot \mathrm{l}^{-1}$ with a supplement of OŠ-1;0.1 mg kg- $\mathrm{kf}^{-1} \mathrm{DM}$ ) and the post-weaning period (concentrated feed for weaned pigs; $0.18 \mathrm{mg} \cdot \mathrm{kg}^{-1}$ of DM), resulted in significant changes in our observation period (Table 6 and 7). As shown also by other authors, a higher intake of Se from the diet is reflected in an elevated concentration of Se as well as the activity of GSH-Px in blood

Table 7. Activities of superoxide dismutase (SOD) and glutathione peroxidase (GSH-Px) in blood $\left(\mathrm{U}_{\mathrm{g}} \mathrm{g}^{-1}\right.$ of $\left.\mathrm{Hb}\right)$, concentrations of malondialdehyde (MDA), sulphhydryl (-SH) groups, vitamin A and E in blood plasma of piglets.

\begin{tabular}{|l|c|c|}
\hline Indices & $\begin{array}{c}\text { End of suckling period } \\
\text { (day 30 after birth) }\end{array}$ & $\begin{array}{c}\text { End of post-weaning period } \\
\text { (day 60 after birth) }\end{array}$ \\
\hline SOD & $2790 \pm 454.3$ & $1959 \pm 328.9^{* *}$ \\
\hline GSH-Px & $92.92 \pm 11.77$ & $156.2 \pm 19.05^{* * *}$ \\
\hline MDA $\left(\mu \mathrm{mol} \cdot \cdot^{-1}\right)$ & $0.576 \pm 0.154$ & $0.36 \pm 0.055^{* *}$ \\
\hline -SH groups $\left(\mathrm{mmol} \cdot 1^{-1}\right)$ & $0.203 \pm 0.066$ & $0.406 \pm 0.044^{* *}$ \\
\hline Vit. A $\left(\mu \mathrm{mol} \cdot \cdot^{-1}\right)$ & $1.25 \pm 0.146$ & $0.878 \pm 0.136^{*}$ \\
\hline Vit. E $\left(\mu \mathrm{mol} \cdot \cdot^{-1}\right)$ & $1.86 \pm 0.272$ & $1.32 \pm 0.135^{*}$ \\
\hline
\end{tabular}

Results are presented as mean $\pm \mathrm{SD}, \mathrm{n}=12 ; * P<0.05 ; * * P<0.01$; $* * * P<0.001$

animal, i.e. the suckling period, is accompanied by an elevated generation of free radicals originating from intensive metabolic processes in cell compartments (Žitňanová et al. 2007). Superoxide anions are a specific substrate for dismutation catalyzed by SOD yielding hydrogen peroxides. The significantly increased SOD activity in erythrocytes of our suckling piglets (Table 7) seems to be associated with the aggravated formation of superoxide anions. These radicals are indicators of uncontrolled oxidation processes that primarily affect lipids, causing their peroxidation, i.e. the chain reaction generating lipoperoxide free radicals from unsaturated fatty acids, which can induce further damage of proteins and DNA (Kelly et al. 1998). The milk of sow contains high amount of lipids that after digestion form a potent source of primary targets for free radicals in the blood plasma of piglets. This fact was confirmed by a higher concentration of MDA and a lower concentration of sulphhydryl groups in blood plasma of suckling piglets in our study. A negative correlation was found between the concentrations of MDA and sulphhydryl groups in blood plasma (Calabrese et al. 1996; Mimic-Oka et al. 2005). On the other hand, the concentration of lipophilic vitamins in blood plasma could be affected by their different dietary intake as well as their ability to participate in the antioxidant defence of organism by free radical scavenging (Table 7).

In conclusion, the dietary changes during the suckling and post-weaning period in piglets have a significant influence on the majority of blood indices under study.

\section{Vplyv prechodu z mliečnej výživy na príjem koncentrovaného krmina na krvné indexy u prasiatok}

Ciel'om pokusu bolo sledovat' hematologické, imunologické a metabolické indexy, ako aj makro-, mikro-minerálny a antioxidačný profil v krvi prasiatok $(\mathrm{n}=12)$ Bielej Ušl'achtilej ošípanej na konci mliečnej výživy (v 30 dni života) a po následnom 30 dňovom príjme koncentrovanej diéty (v 60 dni života). U 60 dňových prasiatok sme zistili štatisticky 
zvýšené indexy: červených krviniek $(P<0,01), \mathrm{Hb}(P<0,01)$, bielych krviniek $(P<0,05)$, celkového Ig $(P<0,05)$, AST $(P<0,01)$, močoviny $(P<0,01)$, Se $(P<0,05)$, GSH-Px $(P<0,001)$, -SH skupín $(P<0,01)$ a významne znížené indexy: albumínu $(P<0,05)$, ALP $(P<0,001)$, LDH $(P<0,01)$, pankreatickej amylázy $(P<0,01)$, celkových lipidov $(P<0,01)$, glukózy $(P<0,01)$, celkového cholesterolu $(P<0,01)$, bilirubínu $(P<0,001), \mathrm{Ca}(P$ $<0,01)$, SOD $(P<0,01)$, MDA $(P<0,01)$, vitamínu A $(P<0,05)$, and vitamínu $\mathrm{E}(P<0,05)$ $\mathrm{v}$ porovnaní $\mathrm{s}$ hodnotami indexov stanovenými na konci mliečnej výživy. Záverom môžeme konštatovat, že zmena mliečnej výživy na príjem koncentrovaného krmiva významne ovplyvnila väčšinu sledovaných krvných indexov u prasiatok.

\section{Acknowledgement}

The study was supported by Grant Agency for Science, VEGA of Slovak Republic, Grant No 1/3486/06 and by Science and Research Assistance Agency, Grant no. APVV-20-027-905

\section{References}

Arthur R, Boyne R 1985: Superoxide-dismutase and glutathione-peroxidase activities in neutrophils from selenium deficient and copper deficient cattle. Life Sci 36: 1569-1575

Baranyiová E, Holub A, Standara S 1990: Age-dependent changes of amino-acid concentration in the bloodplasma of early-weaned piglets. Acta Vet Brno 59: 121-127

Boldižárová K, Grešáková E, Faix S, Mellen M, Leng L 2005: Antioxidant status of lambs fed on diets supplemented with selenite or Se-yeast. J Anim Feed Sci 14: 245-253

Brown DC, Maxwell CV, Erf GF, Davis ME, Singh S, Johnson ZB 2006: The influence of different management systems and age on intestinal morphology, immune cell numbers and mucin production from goblet cells in post-weaning pigs. Vet Immunol Immunopathol 111: 187-198

Calabrese V, Renis M, Calderone A, Russo A, Bercellona ML, Rizza V 1996: Stress proteins and sh-groups in oxidant-induced cell damage after acute ethanol administration in rat. Free Radic Biol Med 20: 391-397

Csapo J, Martin TG, Csapo-Kiss ZS, Hazas ZM 1996: Protein, fats, vitamin and mineral concentrations in porcine colostrum and milk from parturition to 60 days. Int Dairy J 6: 881-902

Egeli AK, Framstad T, Morberg HC 1998: Clinical biochemistry, haematology and body weight in piglets. Acta Vet Scand 39: 381-393

Ellman GL 1958: Tissue sulfhydryl groups. Arch Biochem Biophys 82: 70-77

Gu QP, Xia YM, Ha PC, Butler JA, Whanger PD 1998: Distribution of selenium between plasma fractions in guinea pigs and humans with various intakes of dietary selenium. J Trace Elem Med Biol 12: 8-15

Gu X, Li D, She RP 2002: Effect of weaning on small intestinal structure and function in the piglet. Arch Tierernahr 56: 275-286

Gu X, Li D 2003: Fat nutrition and metabolism in piglets: a review. Anim Feed Sci Technol 109: 151-170

Hampl J, Franz J, Štěpánek J 1980: Immunoglobulin proteosynthesis in organ-cultures from newborn piglets. Acta Vet Brno 49: 67-74

Holub A, Kotrbáček V, Baranyiová E, Ryšavý M 1978a: Vliv 2-deoxy-D-glukosy na konsum diety u selat v časném postnatálním údobí. (Effect of 2-deoxy-D-glucose on diet consumption of piglets in the early postnatal period.) Čs Fysiol 27, 1978: 255-256

Holub A, Kotrbáček V, Ryšavý M, Pánek K 1978b: Vliv insulinu na konsum diety u selat v časném postnatální údobí. (Effect of insulin on diet consumption of piglets in the early postnatal period.) Čs Fyziol 27: 256-257

Holub A 1990: Effect of rearing practices on the water consumption by piglets in the first eight weeks after birth. Acta Vet Brno 59: 129-137

Holub A 1982: Functional development and food intake of piglets. Acta Vet Brno Suppl 5: 5-12

Holub A 1994: Prasnice a selata - nutriční interakce. (In Czech, Sows and piglets - nutritions interactions.) Vet Med Praha 39: 117-132

Jo C, Ahn DU 1998: Fluorometric analysis of 2-thiobarbituric acid reactive substances in turkey. Poult Sci 77: 475-480

Kelly SA, Havrilla CM, Brady TC, Abramo KH, Levin ED 1998: Oxidative stress in toxicology: Established mammalian and emerging piscine model system. Environ Health Perspect 106: 375-386

Klobasa F, Verhahn E, Butler JE 1987: Composition of sow milk during lactation. J Anim Sci 34: 1458-1466

Kováč G, Martinček M, Mudroň V, Cilik D, Demovič T, Pašek I, Stanislavský V, Rúžička S 1990: Odber krvi u ošípaných - Porovannie doteraz používaných metód a popis novšej metódy. Veterinářsví 40: 417-419

Kovářu F, Kovářu H, Fišerová A, Matalová E, Zelníčková P, Landa L, Palíková M 2002: Fetal and postnatal development of T-lymphocyte subpopulations. Acta Vet Brno 71: 495-502

Lauridsen C, Jensen SK 2007: Lipid composition of lactational diets influences the fatty acid profile of the progeny before and after suckling. Animal 1: $952-962$

Lei XG, Dann HM, Ross DA, Cheng WH, Combs GF, Roneker KR 1998: Dietary selenium supplementation is required to support full expression of three selenium-dependent glutathione peroxidases in various tissues of weanling pigs. J Nutr 128: 130-135 
Link R, Kováč G, Foltys V, Kirchnerová K 2007: Composition of sow's milk and secreted metabolic indices after administration of probiotics. Research in Pig Breeding 1: 40-42

Makkink CA, Negulescu GP, Guixin Q, Verstehen MWA 1994: Effect of dietary protein source on feed intake, growth, pancreatic enzyme activities and jejunal morfology in newly-weaned piglets. Br J Nutr 72: 353-368

Mimic-Oka J, Savic-Radojevic A, Pljesa-Ercegovac M, Opacic M, Simic T, Dimkovic N, Simic DV 2005: Evaluation of oxidative stress after repeated intravenous iron supplementation. Ren Fail 27: 345-351

Rodriguez EM, Sanz MT, Romero CD 1994: Critical study of fluorometric determination of selenium in urine. Talanta 12: 2025-2031

Salmon H 1999: The mammary gland and neonate mucosal immunity. Vet Immunol Immunopathol 72: 143-155

Tang M, Laarveld B, Van Kessel AG, Hamilton DL, Estrada A, Patience JF 1999: Effect of segregated early weaning on postweaning small intestinal development in pigs. J Anim Sci 77: 3191-3200

Trávníček J 1960: Chemické složení mleziva a mléka prasnic plemene bílého ušlechtilého. (The chemical composition of Large White sow's colostrum.) Živočišná výroba 5: 497-512

Travnicek J, Racek J, Trefil L, Rodinova H, Kroupova V, Illek J, Doucha J, Pisek L 2008: Activity of glutathione peroxidase (GSH-Px) in the blood of ewes and their lambs receiving the selenium-enriched unicellular alga Chlorella. Czech J Anim Sci 53: 292-298

Trebichavsky I, Patrikova I, Mandel L, Kovaru F, Zahradnickova M 1988: Ontogeny of lymphocytes-T in the pig. Folia Microbiol 33: 329-331

Trujillo-Coutino JE, Figueroa-Velasco JL, Martinez-Aispuro M, Zamora-Zamora V, Cordero-Mora JL, SanchezTorres MT, Cuca-Garcia M, Cervantes-Ramirez M 2007: Plasma urea concentration and growth performance of nursery pigs fed sorghum-soybean meal, low-protein diets. Agrociencia 41: 597-607

Tučková M, Kaštel' R 1999: The methodology for the simultaneous analysis of vitamins A, E, and beta-carotene in animal blood plasma by gradient and isocratic methods of HLPC. Folia Vet 43: 85-91

Van Beers-Schreurs HGM 1996: The changes in the function of the large intestine of weaned pigs. PhD thesis, Univ. of Utrecht, The Netherlands

Wattanakul W, Rooke JA, Stewart AH, English PR, Edwards SA 2007: Effect of milk deprivation during the lactation period on performance and digestive enzyme activities of the piglets following weaning. Animal 138: $1-7$

Wu G, Bazer FW, Davis TA, Jaeger LA, Johnson GA, Kim SW, Knabe DA, Meininger CJ, Spencer TE, Yin YL 2007: Important roles for the arginine family of amino acids in swine nutrition and production. Livestock Sci 112: $8-22$

Zelnickova P, Kovaru H, Pesak S, Lojek A, Matalova E, Ondracek J, Kovaru F 2006: Postnatal functional maturation of blood phagocytes in pig. Vet Immunol Immunopathol 113: 383-391

Žitňanová I, Sumegová K, Šimko M Jr, Maruniaková A, Chovanová Z, Chavko M, Duračková Z 2007: Protein carbonyls as a biomarker of foetal-neonatal hypoxic stress. Clin Biochem 40: 567-570 